\title{
IMPLICATIONS FOR PEAK FLOWS OF THE MARRECAS RIVER BASIN DUE TO CHANGES IN THE BRAZILIAN FOREST CODE
}

\author{
Wagner de Aguiar ${ }^{1 *}$, Silvio C. Sampaio ${ }^{2}$, Julio C. Paisani ${ }^{3}$, Ralpho R. dos Reis ${ }^{2}$ \\ ${ }^{1 *}$ Corresponding author. Universidade Tecnológica Federal do Paraná/ Francisco Beltrão - PR, Brasil. E-mail: \\ wagneraguiar@utfpr.edu.br
}

\section{KEYWORDS}

surface runoff, forestry legis lation, hydrological simulation, land use.

\begin{abstract}
Changes in the Brazilian Forest Code (BFC) have soften the criteria for recovery and conservation of permanent preservation areas (PPAs), enhancing processes related to surface runoff. The aim of this study is to understand the effects of changes in PPA classification criteria established by BFC of 2012 to the detriment of BFC from 1965 considering the surface runoff response in the basin draining the upper Marrecas River valley in the flow peaks. The HEC-HMS model was used to simulate flow peaks considering three land-use scenarios, representative of the current use, adapting it to PPAs fitted to the BFC of 1965 and 2012 and seven precipitation return periods. In the proposed scenarios, the use of BFC of 2012, to the detriment of that from 1965, would imply a PPA reduction from $44.5 \%$ to $13.7 \%$, resulting in a $22.1 \%$ increase in the average flow peaks, not representing, however, a significant reduction in the flow peaks when compared to the scenario representing the current land use. Therefore, when compared to BFC of 1965, in the Brazilian new Forest Code PPAs were reduced by $69.2 \%$, increasing peak flows by up to $30.7 \%$, thus minimizing the legal poss ibilities of flood mitigation to the urban perimeter of Francisco Beltrão, Paraná State, Brazil.
\end{abstract}

\section{INTRODUCTION}

Brazilian Forest Code (Law no. 4,771 of 1965) was in force regulating the activities of land use and occupation considering the 1960s socioeconomic context. However, the Brazilian new Forest Code (Law no. 12,651 of 2012) updated the legislation to the current context and changed several aspects, including the classification criteria of permanent preservation areas (PPAs), significantly reducing the potential area to be recovered by native vegetation (Soares-Filho et al., 2014). These changes in land use and occupation affect water cycle and its availability, which may accentuate the occurrence of natural disasters and environmental damages (Coutinho et al., 2013, Lin et al., 2014; Reis et al., 2015).

The basin drained by the upper Marrecas River valley is occupied by more than $65 \%$ of agricultural areas, characterizing a form of family farm production (Savoldi \& Cunha, 2010). This occupation model caused profound changes in the landscape with the replacement of the Araucaria mo ist forest by agricultural activities (Cassol \& Morais, 2014). These changes may have intensified the recurrent floods affecting the urban perimeter of Francisco Beltrão, Paraná State, Brazil, due to the removal of forest cover, which presents a greater capacity to infiltrate precipitated water when compared to other land uses (Costa et al., 2012; Kibena et al., 2014; Lotz et al., 2017).

According to historical flow and Civil Defense data, from 2010 to 2017 seven flood events were recorded mainly due to the drowning of Marrecas River tributaries crossing the urban perimeter of Francisco Beltrão. The highest flood quota was registered in May 2014, displacing 1050 people due to a daily precipitation of $195 \mathrm{~mm}$ (Andres et al., 2015). The Marrecas River basin has been effectively occupied since 1950, and the main changes in its landscape occurred due to the replacement of natural forest by agricultural and pasture uses in the first three decades and urban occupation in the next years (Machado, 2009).

The replacement of forests by anthropic uses modifies the dynamics between the surface runoff and infiltration, unbalancing the natural balance of waters (Suriya \& Mudgal, 2012). Changes in hydrological cycle caused by deforestation and pressure on water resources require extensive knowledge about the distribution of surface water, with studies on the effects of urbanization (Du et al., 2012; Suriya \& Mudgal, 2012; Niemi et al.,

\footnotetext{
${ }^{2}$ Universidade Estadual do Oeste do Paraná/ Cascavel - PR, Brasil.

${ }^{3}$ Universidade Estadual do Oeste do Paraná/ Francisco B eltrão - PR, Brasil.

Received in: 10-23-2017

Accepted in: 1-31-2018
} 
2017), land use (Githui et al., 2009; Sanyal et al., 2014; Lotz et al., 2017; Mayerhofer et al., 2017), and vegetal cover (Marques et al., 2007; Mu et al., 2015; Zhang et al., 2015; Silva et al., 2016b; Yu et al., 2016) on the balance of continental waters.

Although several authors have studied hydrological simulations of land use scenarios (Ali et al., 2011; Du et al., 2012; Sanyal et al., 2014; Lin et al., 2014; Silva et al., $2016 \mathrm{~b}$ ), some with a practical nature in the management of water resources (Razi et al., 2010; Du et al., 2012; Pereira et al., 2014; Pontes et al., 2016; Kurtz et al., 2017), few have sought to understand the impacts of deforestation (Wan \& Yang, 2007; Kalantari et al., 2014; AlgeetAbarquero et al., 2015) and fewer are those that investigated the implications of peak flows resulting from changes in the limits of PPAs established by the Brazilian Forest Code (BFC) of 2012.
In this context, this study aimed to understand the effects of changes in PPA classification criteria established by BFC of 2012 to the detriment of BFC from 1965 considering the surface runoff response in the basin draining the upper Marrecas River valley in the simulated flow peaks, allowing understanding the effects of changes in BFC on the flood mitigation process of the urban perimeter of Francisco Beltrão, Paraná State, Brazil.

\section{MATERIAL AND METHODS}

This study was carried out in the Marrecas River basin upstream of the urban perimeter of Francisco Beltrão, PR, Brazil, at the control point with geographical coordinates $26^{\circ} 04^{\prime} 53^{\prime \prime} \mathrm{S}$ and $53^{\circ} 04^{\prime} 30^{\prime \prime} \mathrm{W}$. The basin has an average altitude of $736 \mathrm{~m}$ and covers three municipalities in the Paraná State (Marmeleiro, Flor da Serra do Sul, and Francisco Beltrão) (Figure 1).

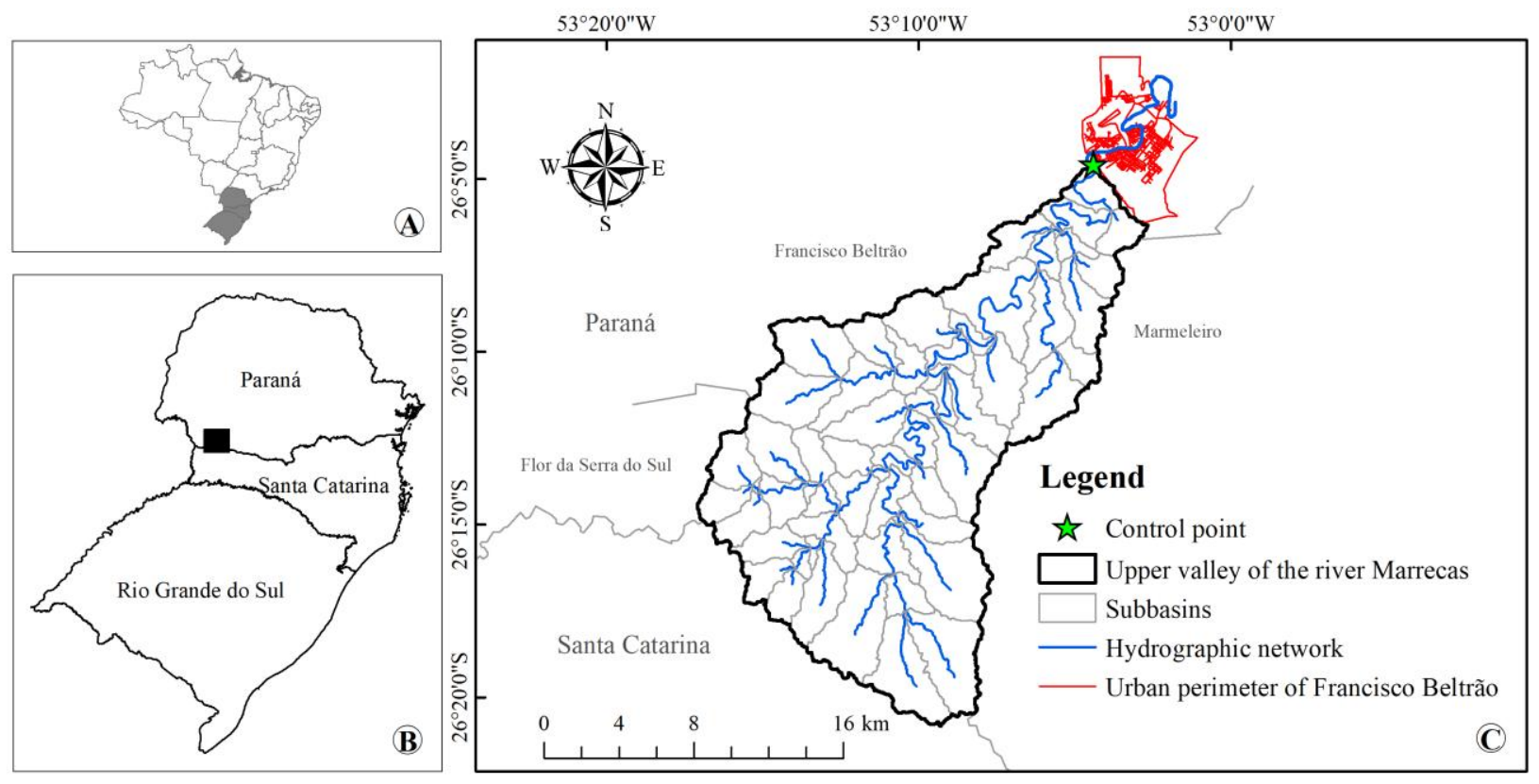

FIGURE 1. Spatial distribution of southern Brazil (A), Marrecas River basin in the Paraná State (B), and basin draining the upper Marrecas River valley, subdivided into 59 sub-basins as the drainage network considered in this study (C).

The control point in the Marrecas River was chosen for having a fluvio metric station (code 65950200/Instituto Águas Paraná), being a point of water collection by the Sanitation Company of Paraná (SANEPAR) for public supplying of a large part of Francisco Beltrão, and representing the point of entry of the river in the urban area, highly affected by floods.

Hydrological simulations considered the peak flow parameter, which is the surface runoff response in the drainage channel, whose overflow to its banks determines the moment of maximum occupation by the flood. Simulations were performed by the HEC-HMS 4.1 (Hydrologic Engineering Center-Hydrologic Modeling System) model, which required a model input with the physical characteristics of the basin and channels, precipitation data, and control specifications with intervals of simulations.

Basin and channel characteristics were obtained by using the extension HEC-GeoHMS (Geospatial Hydrologic Modeling Extension), run by the software
ArcMap 10.1. This extension requires the input of a digital elevation model (DEM) and information of the drainage channels, providing data on surface runoff and flood wave propagation in the channels.

The DEM, with a spatial resolution of $30 \mathrm{~m}$, was preprocessed by delineating the basin draining the upper Marrecas River valley upstream of the urban perimeter of Francisco Beltrão, with an area of $337.9 \mathrm{~km}^{2}$. The basin was subdivided into $59 \mathrm{sub}$-basins in order to improve the spatial representation of the hydrological processes, composed of a hydrographical line generated from the minimum drainage area of $1 \%$ of the total area, whose distribution is shown in Figure 1.

The methods adopted in the HEC-HMS flow peak simulations were pre-selected in the HEC-GeoHMS and chosen based on the information availability on drainage channels and basin: losses by infiltration (SCS curve number method), transformation of effective precipitation into surface runoff (SCS unit hydrograph method), and wave propagation in the channel (Muskingum-Cunge 
method).

Land use was classified by the software Spring with an image of the satellite CBERS 4, PAN sensor from April 2, 2016, generated by the National Institute for Space Research (INPE), randomly chosen. Segmented with a similarity level of 10 and a minimum area of 25 pixels, the uses were individualized by the Bhattacharya classifier at a 95\% acceptance threshold. Use composition took into account the classification key shape, color, and texture possible to be identified in the images.

Three scenarios of land use were generated: reference use (RS), representative of the current use, with an image of April 2, 2016; RS with PPAs adapted to Articles 4 and 61-A of the Brazilian Forest Code of 2012 (BFC2012); and RS with PPAs adapted to Article 2 of the Brazilian Forest Code of 1965 (BFC1965).

The adequacy of PPAs to BFC2012 needed information of average sizes of rural properties, which were collected in the field from random samplings of five properties for each of the 59 sub-basins. It also required the classification of land uses in PPAs defined by the Article 4 prior to July 22, 2008, to define the "consolidated areas in permanent preservation areas" established by the Article 61-A.

The three land use scenarios were reclassified into a magnitude of $\mathrm{CN}$ (curve number), as recommended by the Soil Conservation Service of the US Department of Agriculture (USDA-SCS) and generated by HECGeoHMS. For this, land use scenarios were confronted with hydrological groups of soils of the basin under AMC (antecedent mo isture condition) II (USDA, 1986).

For flow peak simulations, according to the requirements established by $\mathrm{BFC} 1965$ and $\mathrm{BFC} 2012$, PPAs were considered as occupied by native vegetation in the upper Marrecas River valley region (Araucaria mo ist forest), adopting $\mathrm{CN}$ values of forest cover (Roderjan et al., 2002).

The individual analysis of PPAs (riverbanks, surroundings of springs, hilltops, among others) did not take into account the overlapping of the same areas generated by different PPA classes. Therefore, the sum of individualized PPAs exceeded the values of total PPAs adequate to each of BFC.
Flood wave propagation calculated by the Muskingum-Cunge method required information of width, lateral slope, and Manning roughness (n) of the drainage channels. These data were collected in the field by sampling three points for each channel of the 59 subbasins, totaling 177 sampled points.

Precipitations were generated by intensity-durationfrequency curves (IDF), as proposed by Fendrich (2011) for Francisco Beltrão, Paraná State, Brazil, for return periods of $2,5,10,25,50,100$, and 200 years. The duration of each precipitation corresponded to the concentration-time of the basin delimited by the upper Marrecas River valley, calculated by the formula US Corps of Engineers (Silveira, 2005), and distributed by the alternating blocks method with 15-min intervals.

Simulation control specifications were determined in order to obtain all the details of basin responses on the flow distribution. For this, between the beginning and the end of the process, the simulations of each treatment totaled $30 \mathrm{~h}$.

The results consisted of a randomized block design with three treatments representative of the land occupation scenarios. In order to understand variations in flow peaks (response variable) in the land use scenarios under different precipitation probability conditions, treatments were analyzed in seven blocks/replications formed by return periods of $2,5,10,25,50,100$, and 200 years. The results were analyzed by analysis of variance (ANOVA) at $5 \%$ significance. Rejected the null hypothesis $\left(\mathrm{H}_{0}\right)$, the multiple verifications of means of flow peaks generated in each treatment, two by two, were carried out by the Tukey's test at 5\% significance by using the software R.

\section{RES ULTS AND DISCUSS ION}

The adequacy of PPAs in the basin draining the upper Marrecas River valley to the Brazilian Forest Codes of 1965 and 2012 revealed wide differences in territorial occupation. In BFC1965, PPAs comprised $44.5 \%$ of the total basin area $\left(150.4 \mathrm{~km}^{2}\right)$ whereas, in BFC2012, PPA areas occupied $13.7 \%\left(46.3 \mathrm{~km}^{2}\right)$. The spatial distribution of land uses and occupations in the basin draining the upper Marrecas River valley, adequate to the proposed scenarios, is shown in Figure 2.
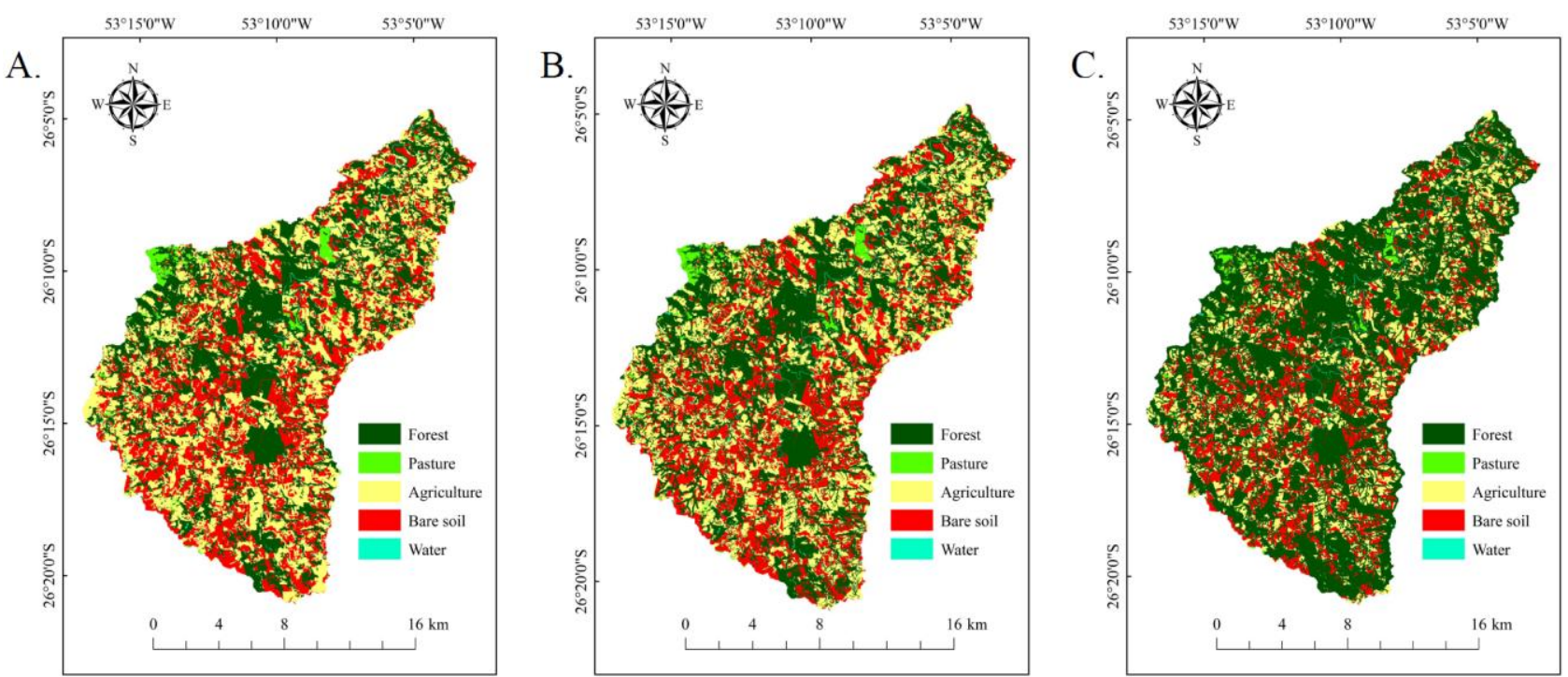

FIGURE 2. Scenarios of reference land use (A), PPAs pursuant to the Brazilian Forest Code of 2012 (B), and PPAs pursuant to the Brazilian Forest Code of 1965 (C). 
Significant reductions in PPAs in complying with BFC2012 are due to the use of risk areas previously prohibited for use in BFC1965. This legislation change is attributed to an intense political interference with the rural sector, which was intended to be amnestied of infractions

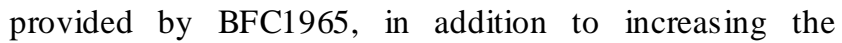
exploitation area (Maccarini \& Silva, 2016) for agriculture and livestock.

In the individualized verifications of PPA classes identified in the basin draining the upper Marrecas River valley, the greatest discrepancy occurred in the hilltop PPAs. In BFC1965, $82.8 \mathrm{~km}^{2}$ were classified as hilltop PPAs whereas no area had the same classification in BFC2012, as shown in Figure 3, which presents the variations of the other PPA classes. Changes in classification criteria of these PPAs reduced the potential area to be protected in hilltops, mounts, mountains, and sierras by $87 \%$ (Soares-Filho et al., 2014).

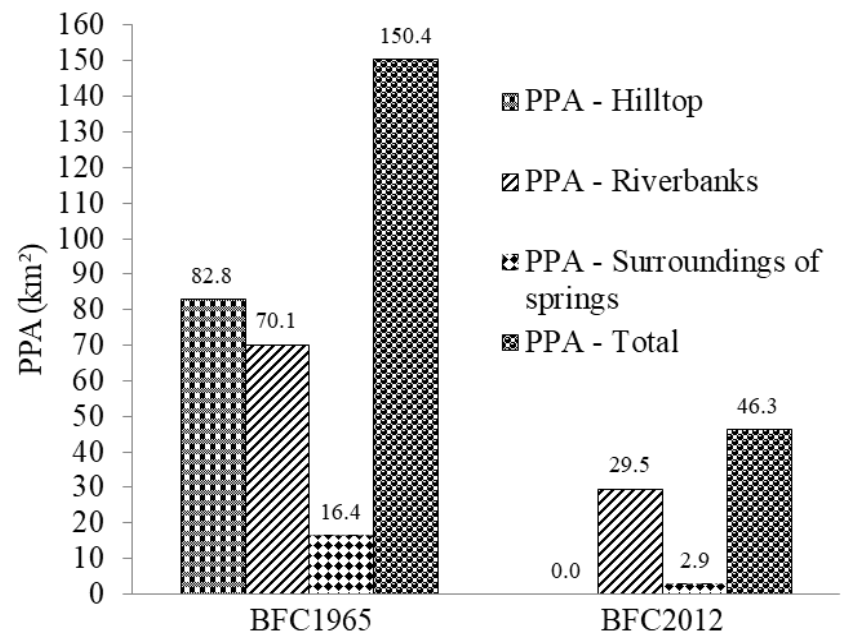

FIGURE 3. Comparative values of PPAs from scenarios adapted to the Brazilian Forest Codes of 1965 (BFC1965) and 2012 (BFC2012).

These changes established by BFC2012 in the classification criteria of hilltop PPAs allow their anthropic use, drastically affecting the hydrodynamic behavior and geological stability of dispersion slopes, which may accentuate floods and landslides in periods with high precipitation volu mes (Coutinho et al., 2013).

Riverbank PPAs decreased from 70.1 to $29.5 \mathrm{~km}^{2}$ whereas PPAs responsible for the maintenance of surroundings of springs reduced from 16.4 to $2.9 \mathrm{~km}^{2}$ when comparing BFC1965 and BFC2012, respectively (Figure 3). The reduction in riverbank PPAs due to the authorization of anthropic use introduced by the Article 61-A of BFC2012 is considered one of the main step backward of the new legislation (Brancalion et al., 2016). However, this reduction may be even greater according to a proposed amendment to the current forest code, currently in process in the National Congress (Reis et al., 2015). Changes in PPA classification criteria described in the transitional provisions of $\mathrm{BFC} 2012$ reduce the potential area to be recovered with native vegetation in Brazil by $58 \%$ in relation to BFC1965 (Soares-Filho et al., 2014).

Changes in BFC did not take into account the function of native vegetation and arrangement in the surface with a greater permeability to intercept and delay the surface runoff (Kibena et al., 2014; Lotz et al., 2017; Mayerhofer et al., 2017). BFC2012 affects the basin draining the upper Marrecas River valley, mainly under the terms of item IX of the Article 4, which deals with the classification rules of hilltop PPAs, and under the terms of the Article 61-A, which authorizes, in PPAs, "to continue agrosilvopastoral, ecotourism, and rural tourism activities in rural areas consolidated until July 22, 2008". The anthropic use of these PPAs potentiates and increases flow peaks, increasing the frequency and severity of flooding (Costa et al., 2012; Kalantari et al., 2014; Sanyal et al., 2014; Algeet-Abarquero et al., 2015).

Considering the changes in PPA classification criteria due to BFC2012 validity, the statistical analyses confirmed the supposed impacts of reducing the native vegetation in the basin draining the upper Marrecas River valley on the flow distribution, as shown in Table 1. The null hypothesis $\left(\mathrm{H}_{\mathrm{o}}\right)$ in the ANOVA was rejected, indicating that changes in land use promoted changes in flow peaks.

TABLE 1. Flow peaks generated for reference scenarios and PPAs adapted to the Brazilian Forest Codes of 2012 and 1965.

\begin{tabular}{|c|c|c|c|c|c|c|c|}
\hline \multirow{3}{*}{$\begin{array}{l}\text { Treat ment (scenarios of } \\
\text { land use }\end{array}$} & \multicolumn{7}{|c|}{ Peak flow $\left(\mathrm{m}^{3} \mathrm{~s}^{-1}\right)$} \\
\hline & \multicolumn{7}{|c|}{ Precipitation return period (year) } \\
\hline & 2 & 5 & 10 & 25 & 50 & 100 & 200 \\
\hline Reference ${ }^{\mathrm{a}^{*}}$ & 507.3 & 728.3 & 937.4 & 1295.3 & 1639.7 & 2052.0 & 2543.5 \\
\hline PPAs - BFC2012 & 473.8 & 681.4 & 891.8 & 1239.6 & 1576.3 & 1980.0 & 2460.8 \\
\hline PPAs - BFC $1965^{\mathrm{b}}$ & 362.6 & 540.5 & 715.4 & 1023.8 & 1318.5 & 1690.2 & 2132.9 \\
\hline
\end{tabular}

*Equal letters represent statistical equality between flow peaks generated by land use scenarios, two by two, by the Tukey's test at $5 \%$ significance.

The multiple analyzes of means of flow rates by the Tukey's test at 5\% significance level revealed significant differences between flow peaks generated by BFC1965 and those produced by BFC2012 and RS. However, no significant differences were observed between flow peaks generated by BFC2012 and RS.

Statistical interpretations confirm the influence exerted by the vegetation cover on flow distribution. Flow peaks generated by BFC2012 and RS increased significantly when compared to those produced by BFC1965. However, no significant reductions were observed in flow peaks produced by $\mathrm{BFC} 2012$ in relation to RS, indicating that PPA adequacy to BFC2012 does not differ from the representative scenario of the current land use in relation to the retention of surface runoff. These statistical equalities between flow peaks generated by 
BFC2012 and RS make us think that changes in BFC minimize the legal possibilities of flood mitigation in the urban perimeter of Francisco Beltrão.

Forest substitution in PPAs in the basin drain ing the upper Marrecas River valley by anthropic uses increases surface runoff and soil losses by reducing evapotranspiration, vegetation interception, protection caused by roots, among others (Githui et al., 2009; Zhang et al., 2015; Eum et al., 2016; Silva et al., 2016b; Lotz et al., 2017). The current agricultural cultivation, which is the main substitute for forest cover, compacts soil horizons mainly due to agricultural machinery traffic, reducing infiltration rates and increasing soil bulk density (Ankeny et al., 1990, Abu-Hamdeh, 2003; Gómez-Rodríguez et al., 2013, Feitos a et al., 2015; Silva et al., 2016a).

The average percentage increase in flow peaks generated by BFC2012, when compared to those produced by $\mathrm{BFC} 1965$, was $22.1 \%$, and could reach $30.7 \%$ for the return period with higher frequency ( 2 years). Considering the registered occurrence of seven flood events in the urban perimeter of Francisco Beltrão in the last 7 years, this last percentage may better represent the increase in flow peaks for this period, which is due to the beginning of validity of Brazil's new Forest Code (2012), to the detriment of the Brazilian Forest Code of 1965.

\section{CONCLUSIONS}

Considering the Brazilian Forest Code of 2012, PPAs in the basin draining the upper Marrecas River valley would be reduced by $69.2 \%$ when compared to the Brazilian Forest Code of 1965. In this case, the largest losses would occur in hilltop areas, responsible for the retention of a large portion of surface runoff, the main factor responsible for flood events in the urban perimeter of Franc is co Beltrão, Paraná State, Brazil.

The simulated flow peaks increased by up to $30.7 \%$ for the 2-year precipitation return period, indicating that the higher the precipitation frequencies are, the greater the differences between flow peaks generated by the scenarios of the Brazilian Forest Codes of 1965 and 2012.

\section{ACKNOWLEDGEMENTS}

To the UTFPR-FB (Federal Technological University of Paraná, Campus Francisco Beltrão), PGEA GRI (Graduate Program in Agricultural Engineering of UNIOESTE, Campus Cascavel), Araucária Foundation, CAPES (Coordination for the Improvement of Higher Education Personnel), 3rd Independent Firemen Subgroup of the Fire Department of Paraná, and Laboratory of Geoprocessing of UNIOESTE, Campus Francisco Beltrão.

\section{REFERENCES}

Abu-Hamdeh NH (2003) Compaction and subsoiling effects on corn growth and soil bulk density. Soil Science Society of A merica Journal 67(4):213-1219. DOI: http://dx.doi.org/10.2136/sssaj2003.1213

Algeet-Abarquero N, Marchamalo M, Bonatti J, Fernández-Moya J, Moussa R (2015) Implications of land use change on runoff generation at the plot scale in the humid tropics of Costa Rica. Catena 135:263-270. DOI: http://dx.doi.org/10.1016/j.catena.2015.08.004
Ali M, Khan SJ, Aslam I, Khan Z (2011)

Simulation of the impacts of land-use change on surface runoff of Lai Nullah Basin in Islamabad, Pakistan. Landscape and Urban Planning 102:271-279. DOI: http://dx.doi.org/10.1016/j.landurbplan.2011.05.006

Andres J, Caneparo SC, Hendges ER (2015) Riscos de Inundação na Cidade de Francisco Beltrão (PR) por meio de Combinação Linear Ponderada Difusa. In: Simpósio Brasileiro de Sensoriamento Remoto. João Pessoa. Anais...

Ankeny MD, Kaspar TC, Horton R (1990)

Characterization of tillage and traffic effects on unconfined infiltration measurements. Soil Science Society of America Journal 54(3):837-840. DOI: http://dx.doi.org/10.2136/sssaj1990.036159950054000300 $37 \mathrm{x}$

Brancalion PHS, Garcia LC, Loyola R, Rodrigues RR, Pillar VD, Lewinsohn TM (2016) Análise crítica da Lei de proteção da vegetação nativa (2012), que substituiu o antigo código florestal: atualizações e ações em curso. Natureza \& Conservação 14:e 1-e 16. DOI: http://dx.doi.org/10.1016/j.ncon.2016.03.004

Cassol HLG, Moraes EC (2014) Recorte municipal do sudeste e sudoeste paranaense: relação entre os fatores sociais e econômicos com o desflorestamento na Floresta Ombrófila Mista? Rev ista Espinhaço 3(1):43-61.

Costa J, Costa A, Poleto C (2012) Telhado verde: redução e retardo do escoamento superficial. Revis ta de estudos ambientais (On line) 14(2esp):50-56.

Coutinho MP, Medeiros JD, Soriano É, Londe LR, Leal PJD, Saito SM (2013) O Código Florestal Atual (Lei Federal $n^{\circ} 12.651 / 2012$ ) e suas implicações na prevenção de desastres naturais. Sustentabilidade em Debate 4(2):237-256.

Du J, Qian L, Rui H, Zuo T, Zheng D, Xu Y, Xu C-Y (2012) Assessing the effects of urbanization on annual runoff and flood events using an integrated hydrological modeling system for Qinhuai River basin, China. Journal of Hydrology 464-465:127-139. DOI:

http://dx.doi.org/10.1016/j.jhydrol.2012.06.057

Eum H-I, Dibike Y, Prowse T (2016) Comparative evaluation of the effects of climate and land-cover changes on hydrologic responses of the MuskegRiver, A lberta, Canada. Journal of Hydro logy: Reg ional Studies 8:198221. DOI: http://d x.doi.org/10.1016/j.ejrh.2016.10.003

Feitosa JR, Fernandes HC, Teixeira MM, Cecon PR (2015) Influência da pressão interna dos pneus e da velocidade de deslocamento nos parâmetros operacionais de um trator agríco la e nas propriedades físicas do solo. Engenharia Agrícola 35(1):117-127. DOI: http://dx.doi.org/10.1590/1809-4430Eng.Agric.v35n 1p117-127/2015

Fendrich R (2011) Chuvas intens as para obras de drenagem no Estado do Paraná. 3 ed. ampl. Curitiba, O Autor. 89p 
Githui F, Mutua F, Bauwens W (2009) Estimating the impacts of land-cover change on runoff using the soil and water as ses sment tool (SWAT): case study of Nzoia catchment, Kenya. Hydrological Sciences Journal 54(5):899-908. DOI:

http://dx.doi.org/10.1623/hysj.54.5.899

Gómez-Rodríguez K, Camacho-Tamayo JH, VélezSánchez JE (2013) Changes in water availability in the soil due to tractor traffic. Engenharia Agrícola 33(6):11561164. DOI: http://dx.doi.org/10.1590/S010069162013000600008

Kalantari Z, Lyon SW, Folkeson L, French HK, Stolte J, Janss on PE, Sassner M (2014) Quantifying the hydrological impact of simulated changes in land use on peak discharge in a small catch ment. Science of the Total Environment 466-467:741-754. DOI: http://dx.doi.org/10.1016/j.scitotenv.2013.07.047

Kibena J, Nhapi I, Gu mindoga W (2014) Assessing the relationship between water quality para meters and changes in landuse patterns in the Upper Manyame River, Zimbabwe. Physics and Chemistry of the Earth 67-69:153163. DOI: http://d x.doi.org/10.1016/j.pce.2013.09.017

Kurtz W, Lapin A, Schilling OS, Tang Q, Schiller E, Braun T, Hunkeler D, Vereecken H, Sudicky E, Kropf P (2017) Integrating hydrological modelling, data assimilation and cloud computing for real-time management of water resources. Environmental Modelling \& Software 93:418-435. DOI:

http://dx.doi.org/10.1016/j.envsoft.2017.03.011

Lin K, Lv F, Chen L, Singh VP, Zhang Q, Chen X (2014) Xinanjiang model co mbined with Curve Nu mber to simu late the effect of land use change on environmental flow. Journal of Hydrology 519:3142-3152. DOI: http://dx.doi.org/10.1016/j.jhydrol.2014.10.049

Lotz T, Opp C, He X (2017) Factors of runoff generation in the Dongting Lake basin based on a SWAT model and implications of recent land cover change. Quaternary International 30:1-9. DOI: http://dx.doi.org/10.1016/j.quaint.2017.03.057

Maccarini TB, Silva AA (2016) relação entre o código florestal brasileiro e os desastres naturais. Revista Ordem Pública 9(1):223-233.

Machado G(2009) Transformações na paisagem da bacia do rio Marrecas (SW/PR) e perspectivas de desenvolvimento territorial. Tese, Universidade Estdual Paulista "Julio de Mesquita Filho", Faculdade de Ciência e Tecnologia.

Marques MJ, Bienes R, Jiménez L, Pérez-Rodríguez R (2007) Effect of vegetal cover on runoff and soil erosion under light intensity events. Rainfall simulation over USLE plots. Science of the Total Environ ment 378:161 165. DOI:

http://dx.doi.org/10.1016/j.scitotenv.2007.01.043

Mayerhofer C, Meiß1 G, Klebinder K, Kohl B, Markart G (2017) Comparis on of the results of a small-plot and a large-plot rainfall simu lator - Effects of land use and land cover on surface runoff in Alpine catchments. Catena 156:184-196. DOI: http://dx.doi.org/10.1016/j.catena.2017.04.009
Mu W, Yu F, Li C, Xie Y, Tian J, Liu J, Zhao N

(2015) Effects of rainfall intensity and slope gradient on runoff and soil moisture content on different growing stages of spring maize. Water 7(6):2990-3008. DOI: http://dx.doi.org/10.3390/w7062990

Niemi TJ, Warsta L, Taka M, Hickman B, Pulkkinen S, Krebs G, Moisseev DN, Koivusalo H, Kokkonen T (2017) Applicability of open rainfall data to event-scale urban rainfall-runoff modelling. Journal of Hydrology 547:143155. DOI: http://dx.doi.org/10.1016/j.jhydrol.2017.01.056

Pereira DR, Martinez MA, Almeida AQ, Pruski FF, Silva DD, Zonta JH (2014) Hydrological simu lation using SWAT model in headwatger basin in Southeast Brazil. Engenharia Agrícola 34(4):789-799. DOI: http://dx.doi.org/10.1590/S0100-69162014000400018

Pontes LM, Viola MR, Silva MLN, Bispo DFA, Curi N (2016) Hydrological modeling of tributaries of Cantareira sytem, southeast Brazil, with the SWAT model.

Engenharia Agrícola 36(6):1037-1049. DOI:

http://dx.doi.org/10.1590/1809-4430-

Eng.Agric.v36n6p1037-1049/2016

Razi MAM, Ariffin J, Tahir T, Arish AM (2010) Flood estimation studies using hydrologic modeling system (HEC-HMS) for Johor River, Malaysia. Journal of Applied Sciences 10:930-939. DOI:

http://dx.doi.org/10.3923/jas.2010.930.939

Re is LC, Reis TES, Saab OJGA, Re is AS, Batista BG (2015) Código Florestal Brasileiro: Impactos econômicos e sociais no município de Bandeirantes-PR. Engenharia Agrícola 35(4):778-788. DOI: http://dx.doi.org/10.1590/1809-4430-

Eng.Agric.v35n4p778-788/2015

Roderjan CV, Galvão F, Kuniyoshi YS, Hatschbach GG (2002) As unidades fitogeográficas do estado do Paraná, Brasil. Ciência e A mbiente 24(1):75-42.

Sanyal J, Densmore AL, Carbonneau P (2014) Analysing the effect of land-use/cover changes at sub-catchment levels on downstream flood peaks: A semi-d istributed modelling approach with sparse data. Catena 118:28-40. DOI: http://dx.doi.org/10.1016/j.catena.2014.01.015

Savoldi A, Cunha LA (2010) Uma abordagem sobre a agricultura familiar, PRONAF e a modernização da agricultura no Sudoeste do Paraná na década de 1970. Revista Geografar 5(1):25-45.

Silva WM, Bianchini A, Cunha CA (2016a) Modeling and correction of soil penetration resistance for variations in soil moisture and soil bulk density. Engenharia Agrícola 36(3):449-459. DOI: http://d x.doi.org/10.1590/1809-4430Eng.Agric.v36n3p449-459/2016 
Silva VPR, Silva MT, Souza EP (2016b) Influence of land use change on sediment yield: A case study of the submiddle of the São Francisco river basin. Engenharia Agrícola 36(6):1005-1015. DOI:

http://dx.doi.org/10.1590/1809-4430-

Eng.Agric.v36n6p1005-1015/2016

Silveira ALL (2005) Desempenho de fórmulas de te mpo de concentração em bacias urbanas e rurais. Revista Brasileira de Recursos Hídricos 10(1):5-23. DOI: http://dx.doi.org/10.21168/rbrh.v10n1.p5-29

Soares-Filho B, Rajão R, Macedo M, Carneiro A, Costa W, Coe M, Rodrigues H, Alencar A (2014) Cracking Brazil's Forest Code. Science 344(6182):363-364. DOI: http://dx.doi.org/10.1126/science.1246663

Suriya S, Mudgal BV (2012) Impact of urbanization on flooding: The thirusoolam sub watershed - A case study. Journal of Hydrology 412-413:210-219. DOI: http://dx.doi.org/10.1016/j.jhydrol.2011.05.008
USDA - United States Departament of

Agriculture (1986) Natural Resources Conservation Service. Urban Hydrology for Small Watersheds. In: TR55. 2 ed. Available in:

https://www.nrcs.usda.gov/Internet/FSE_DOCUMENTS/s telprdb1044171.pdf. Acces sed: Aug 17, 2016.

Wan R, Yang G (2007) Influence of land use/cover change on storm runoff - a case study of Xit iaoxi River Basin in upstream of Taihu Lake watershed. Chinese Geographical Science 17(4):349-356. DOI:

http://dx.doi.org/10.1007/s 11769-007-0349-6

Yu Y, Loiskandl W, Kaul H-P, Himmelbauer M, Wei W, Chen L, Bodner G (2016) Estimation of runoff mitigation by morphologically different cover crop root systems . Journal of Hydrology 538:667-676. DOI: http://dx.doi.org/10.1016/j.jhydrol.2016.04.060

Zhang L, Wang J, Bai Z, Lv C (2015) Effects of vegetation on runoff and soil erosion on reclaimed land in an opencast coal-mine dump in a loess area. Catena 128:44-53. DOI: http://dx.doi.org/10.1016/j.catena.2015.01.016 